\title{
Gratitude training to improve subjective well-being among adolescents living in orphanages
}

\author{
Putri Megawati $^{1}$, Sri Lestari ${ }^{2}$, Rini Lestari ${ }^{3}$ \\ ${ }^{1,2,3}$ Post Graduate Program on Profesional Psychology Universitas Muhammadiyah Surakarta, Indonesia \\ ${ }^{1}$ megaputri41@yahoo.com, ${ }^{2}$ sri.lestari@ums.ac.id, ${ }^{3}$ rini.lestari@ums.ac.id
}

ARTICLE INFO

Article history

Received 6 March 2018

Revised 24 November 2018

Accepted 13 December 2018

Keywords

gratitude training

subjective well-being

quasi experiment

adolescents in orphanages

\begin{abstract}
Adolescents who live in orphanages need to adjust to the orphanage's conditions and rules to meet their subjective well-being. The fact shows not all adolescents living in orphanages are able to achieve subjective well-being in their lives. The purpose of this study was to examine the effect of gratitude training in improving the subjective well-being of adolescents in an orphanage. A quasiexperimental design with a nonequivalent control group design was used in this study. Sixteen orphanage boys with moderately subjective well-being level participated in this study. Data were analyzed using non-parametric statistical analysis Mann Whitney u test and Wilcoxon. The results show that gratitude training is effective for improving the subjective well-being of the participants. The most improvement of subjective well-being was experienced by the participants who actively communicate with caregivers and optimistically achieve goals and expectations. The implication of this research is that to achieve subjective well-being in everyday live we should develop grateful behavior.
\end{abstract}

\section{Introduction}

Everyone has the opportunity to achieve happiness in their life, one of which is marked by the success of achieving subjective well-being. Diener (2000) expresses the concept of subjective well-being, which includes experiencing pleasant events, feeling positive emotions, rarely feeling negative moods, and feeling satisfying life. Diener \& Scollon (2003) add that subjective well-being describes a person's thoughts and feelings towards their own life. Subjective well-being is a feeling of joy or positive emotion of satisfaction with life and the absence of a state of depression, anxiety, or other negative emotions.

Subjective well-being has an important role, such as increasing optimism, being more satisfied in looking at one's own life, feeling full of hope about one's own future (Diener, Suh, Lucas, \& Smith, 1999), having good social skills, displaying physical attractiveness, and being able to achieve goals (Diener, 2000). Individual's quality of life can be predicted from the welfare of life that affects the achievement of success in various spheres of life (Pavot \& Diener, 2004).

In fact, not everyone can prosper in their life. Adolescents living in orphanages are seen as a group that is susceptible to issues of welfare. In addition to losing one or both parents, adolescents living in orphanages also experience problems of self-adjusting to the orphanage environment, both related to the orphanage regulations, activities in the 
orphanage, and interactions with peers and caregivers. This situation requires them to be able to adapt well to their conditions. Adolescents in orphanages who experience difficulties in adapting to social change feel depressed, so it leads to inconvenience, deviant behavior, and dissatisfied feeling with the conditions of life in the orphanage (Sengendo \& Nambi, 1997). Adolescents raised in orphanages also have a tendency to compare their living conditions with those of others, so that the tendency can influence their subjective wellbeing (Zotova, Tarasova, \& Syutkina, 2016). A study of Yuniana (2013) reveals that adolescents in orphanages have low life satisfaction that appears in pessimistic attitudes in looking toward their future, and they think of not getting attention, they have a negative affect of feeling sad that there is no opportunity to serve their parents, and they feel that they are being shunned by their friends. These adolescents feel sad because they are far from their parents, lack of family support, and have no place to share their stories when they have a problem and feel uncomfortable living in an orphanage.

Interviews with the orphanage caregivers and discussions performed on 12 adolescents raised at Orphanage $\mathrm{X}$ and Orphanage $\mathrm{Y}$, showed that these adolescents felt they were living in prison because of many regulations applied, lacking interest in daily activities, and having poor social relations with the caregivers. Furthermore, adolescents in orphanages also show negative affect in the form of anger when they are punished for making mistakes, fear of telling caregivers when they have a problem, feeling uncomfortable living in an orphanage, and being sad because they are far from their parents. These findings indicate low subjective well-being. The low subjective well-being has an impact on the those adolescents' self-esteem (Khairat \& Adiyanti, 2015), being pessimistic about their life (Sabiq \& Miftahuddin, 2017), giving up easily and despair (Pavot \& Diener, 2004), and having poor academic performance (Piko \& Hamvai, 2010).

Based on the top down theory, the subjective well-being of a person depends on the positive point of view that someone uses to perceive and interpret the conditions or events they experienced. This means whether a person achieved one's subjective well-being is determined by cognitive processes that actively determine the arrangement of obtained information. Therefore, changing one's perceptions or beliefs may improve subjective wellbeing (Diener et al., 1999).

A gratitude training may stimulate the process of changing one's perception of unpleasant conditions into an acceptable situation. Clore, Ortony \& Foss (1987) define gratitude as the self-habituation of positive thinking for the grace people received and positively behaving to show gratitude to the source that gives grace or kindness to oneself. Gratitude is a character of a person who has positive thought and they present their life more positively (Wood, Joseph, \& Maltby, 2009).

Peterson \& Seligman (2004) express two ways of being grateful to the main source (God) — transpersonal; and in the intermediary (human)—personal. This research invites adolescents in orphanages to offer their gratitude transpersonally and personally. Through gratitude training, it is expected that adolescents will be able to take lessons from the events in their lives and develop positive emotions in order to subjectively achieve prosperity.

A number of studies have proven that gratitude training has been widely used to improve subjective well-being. Emmons \& McCullough's (2003) study found gratitude by doing a daily blessing calculation for 16 days can encourage the development of positive emotions in students and encouragement to do good for others. Other studies prove that gratitude training is effective in improving subjective well-being and self-esteem of adult women in the UK (Gilek, 2010), improving the subjective well-being of poor people in Surakarta (Anggarani, Andayani, \& Karyanta, 2010), and improving the subjective wellbeing of sarong workers of Alimin Majalaya (Kusumah, 2015). 
In contrast to previous studies administered to adult respondents, this study was conducted on foster adolescents living in orphanages. When compared with previous studies, this study is different in its material because it invites participants to do transpersonal and personal gratitude. Meanwhile, the intervention material in the previous studies was only carried out transpersonally (Safitri, 2013) or only personally (Emmons \& McCullough, 2003; Kusumah, 2015).

Based on the above discussion, the problem that is examined in this study is whether gratitude training can improve subjective well-being on adolescents living in orphanages? Therefore, the aim of this study is to determine the effect of gratitude training in improving the subjective well-being of adolescents living in orphanages.

\section{Method}

The research design used in this study was quasi-experimental in the form of nonequivalent control group design. This research was conducted in 2 orphanages, i.e., Orphanage $\mathrm{X}$ and Orphanage Y, which specifically cared for male adolescents. The research procedure began by screening 27 adolescents in orphanage $\mathrm{X}$ and 19 adolescents in orphanage Y. Screening was done by administering a subjective well-being and obtained 16 participants-with 7 participants from Orphanage $\mathrm{X}$ and 9 from orphanage $\mathrm{Y}$. The screening results also serve as the pre-treatment data. All of the participants were male with moderate level of subjective well-being (based on the results of scale measurements during screening and those who provided their consent to be involved in the study). The participants were divided into two groups conducted by convenience nonrandom sampling, which is based on consideration of practical criteria or by chance (Etikan, Musa, \& Alkasim, 2016). The adolescents from Orphanage $\mathrm{X}$ became the experimental group, while the adolescents from orphanage $\mathrm{Y}$ became the control group. The determination of the participants in the experimental group and the control group coming from different orphanages was carried out to minimize the threat of internal validity, i.e., imitation of treatment (Latipun, 2002).

The instruments for measuring subjective well-being consist of two scales. First is the flourishing scale which reveals cognitive aspects (life satisfaction) consisting of 8 items. Examples of the items are: (a) I live a purposeful and meaningful life; (b) my social relations are very supportive and satisfying for me; (c) I am involved and interested in my daily activities. Second is the SPANE scale, which reveals affective aspects consisting of 10 items. Examples of the items are: (a) Comfortable; (b) Not Comfortable; (c) Happy; (d) Sad.

The subjective well-being scale in this study was adapted from the scale used by (Aesiyah, 2013) on adolescents who also lived in an orphanage. The flourishing scale has an item differential power between .335-.705 and alpha reliability coefficient of .799. The SPANE scale has an item differential power of .390-.6652 and has an alpha reliability coefficient of .816. In this study, a semi-structured interview method was also conducted to obtain additional data related to the subjective well-being of the adolescents living in orphanages before and after treatment.

Gratitude training invites the participants to practice recognizing the thoughts that support the expressions of gratitude for their received blessings (Emmons \& Shelton, 2002) and applying them through behavior by writing a gratitude journaling thanks for their received blessings (Emmons \& McCullough, 2003). Adolescents living in orphanages are also trained to identify their sources that give them grace and actualize their expressions of gratitude (Watkins, 2003). The gratitude training program consists of 4 sessions (3 meetings 
for 3 weeks). The 1 st meeting's duration is 180 minutes, the 2 nd meeting's duration is 235 minutes, and the 3rd meeting's is 130 minutes. A one-week pause was given between one meeting and the next, to give an opportunity for the participants to practice the knowledge they have obtained from the previous meeting. The description of the contents of the gratitude training module material is shown in Table 1.

Table 1

Material Contents in the Gratitude Training Module

\begin{tabular}{|c|c|c|c|}
\hline Meeting & Session or material & Objective & Implementation \\
\hline \multirow[t]{2}{*}{ I } & $\begin{array}{l}\text { Session I } \\
\text { Introduction for supporting } \\
\text { thoughts of gratitude for } \\
\text { blessings }\end{array}$ & $\begin{array}{l}\text { Participants are able to think } \\
\text { positively on their lives in } \\
\text { order to increase life } \\
\text { satisfaction }\end{array}$ & $\begin{array}{l}\text { Opening } \\
\text { Introduction } \\
\text { Getting acquainted with } \\
\text { gratitude } \\
\text { Recognizing thoughts that } \\
\text { support gratitude for } \\
\text { received blessing }\end{array}$ \\
\hline & $\begin{array}{l}\text { Session II } \\
\text { Learning to write a journal } \\
\text { of gratitude for their } \\
\text { received blessings }\end{array}$ & $\begin{array}{l}\text { Participants are able to } \\
\text { behave positively by } \\
\text { detailing and describing the } \\
\text { goodness or blessings } \\
\text { ( } 3-5 \text { blessings every day for } \\
7 \text { days) to more often feel } \\
\text { positive affects }\end{array}$ & $\begin{array}{l}\text { Giving a home assignment } \\
\text { to write a journal of } \\
\text { gratitude for their received } \\
\text { blessings. } \\
\text { Closing, impressions and } \\
\text { expectations, filling out } \\
\text { the training evaluation } \\
\text { sheet. }\end{array}$ \\
\hline \multirow[t]{2}{*}{ II } & $\begin{array}{l}\text { Session III } \\
\text { Identifying sources of } \\
\text { transpersonal and personal } \\
\text { blessings }\end{array}$ & $\begin{array}{l}\text { Participants are able to } \\
\text { behave positively by finding } \\
\text { and identifying sources that } \\
\text { give goodness or blessings } \\
\text { to more often feel positive } \\
\text { affect }\end{array}$ & $\begin{array}{l}\text { Opening and ice breaking } \\
\text { Review or discussion of } \\
\text { previous assignments } \\
\text { Identifying sources of } \\
\text { blessings }\end{array}$ \\
\hline & $\begin{array}{l}\text { Session IV } \\
\text { The application of } \\
\text { transpersonal and personal } \\
\text { expressions of gratitude }\end{array}$ & $\begin{array}{l}\text { Participants are able to } \\
\text { behave positively by } \\
\text { applying gratitude behavior } \\
\text { to sources giving goodness } \\
\text { or blessings in both spoken } \\
\text { and written, for them to } \\
\text { often feel positive affect }\end{array}$ & $\begin{array}{l}\text { Exercises on transpersonal } \\
\text { expressions of gratitude } \\
\text { with dhikr relaxation } \\
\text { Practicing behavior of } \\
\text { personal gratitude by } \\
\text { writing and submitting } \\
\text { letters of gratitude } \\
\text { Closing }\end{array}$ \\
\hline III & $\begin{array}{l}\text { Maintaining grateful } \\
\text { behavior for the blessings } \\
\text { and building commitment } \\
\text { to look after them. }\end{array}$ & $\begin{array}{l}\text { Participants are able to } \\
\text { maintain grateful behavior } \\
\text { for their received blessings } \\
\text { promise to themselves to } \\
\text { always be grateful for the } \\
\text { blessings of happiness. In } \\
\text { addition, participants can } \\
\text { feel the benefits after } \\
\text { participating in the gratitude } \\
\text { training. }\end{array}$ & $\begin{array}{l}\text { Opening and ice breaking } \\
\text { Reviewing and discussing } \\
\text { assignments. } \\
\text { Motivating participants to } \\
\text { maintain the behavior of } \\
\text { gratitude for daily } \\
\text { blessings } \\
\text { Closing }\end{array}$ \\
\hline
\end{tabular}

In this study, the experimental group received the gratitude training, while the control group received a compensation in the form of group counselling to motivate them to live in the orphanage. To identify the effect of gratitude training, the experimental group was given a subjective well-being scale during the pretest, posttest ( 3 days after training), and follow up ( 2 weeks after training). Schematically, the experimental design can be described as listed in Table 2. 
Table 2

Experimental Design

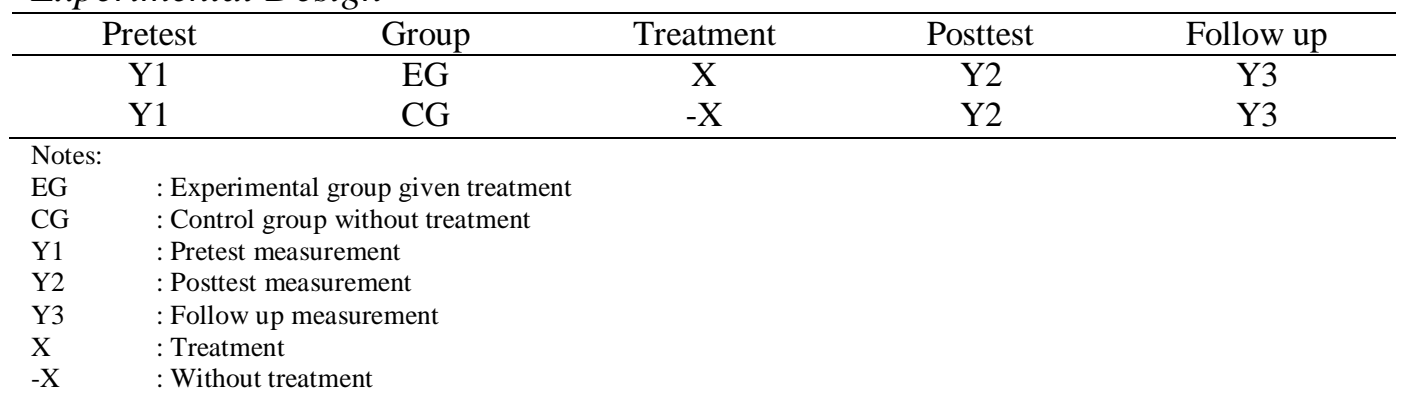

The data analysis technique used in this study was the Mann Whitney U Test, to test the differences between the two groups - the experimental group and the control group. Meanwhile, Wilcoxon was used to look at the improvement of subjective well-being scores in the experimental group between the pretest - posttest and posttest- follow up (Santoso, 2003).

\section{Results}

The calculation of subjective well-being was done separately in each aspect, i.e., cognitive aspects (life satisfaction) and affective aspects. The categorization for the level of subjective well-being uses a hypothetical mean. The mean difference in the subjective well-being scores on cognitive aspects (life satisfaction) for the experimental group at the pretest, which was 35.71 (medium category), increased after posttest to 45.28 (high category) and experienced a slight increase at the follow up to 45.57 (high category). Meanwhile, the increase in the mean scores of subjective well-being on cognitive aspects is shown in Figure 1.

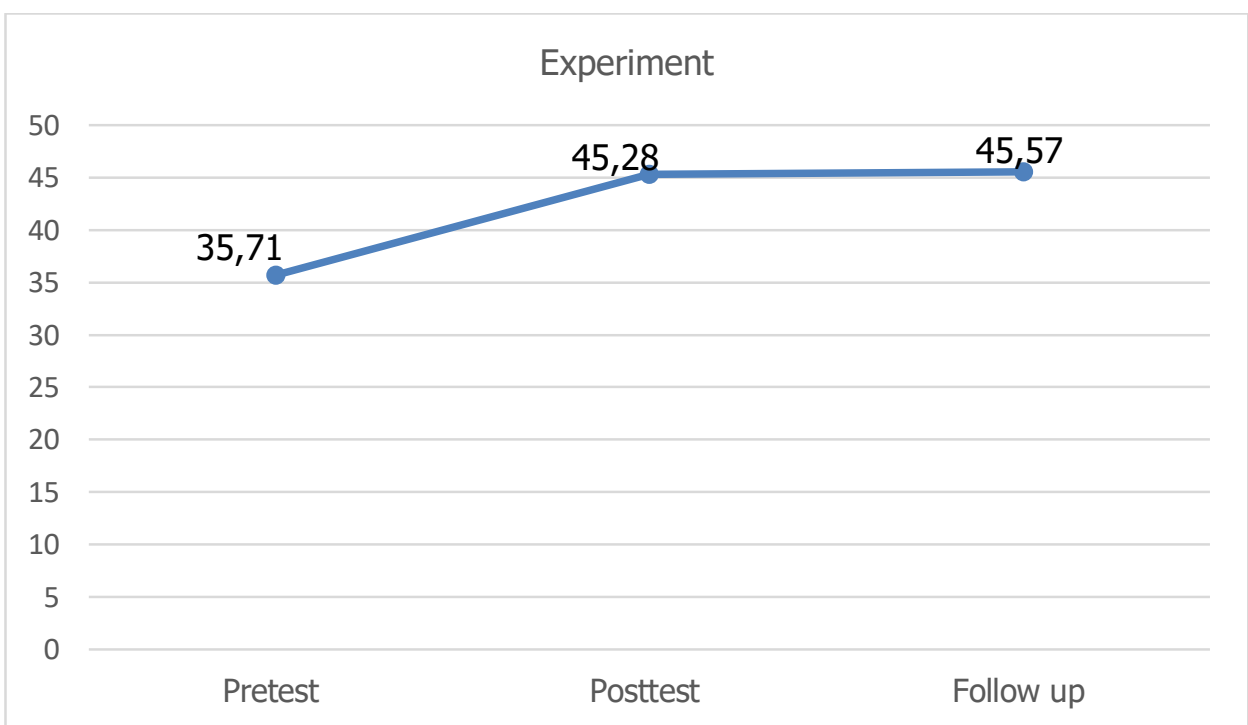

Figure 1. The mean scores for subjective well-being on cognitive aspects (life satisfaction)

The increase in the mean scores of affective aspects in subjective well-being is shown in Figure 2. The mean score in the pretest was in moderate category, while in the posttest and follow up were in high category with value $2.57,8.71$ and 8.85 , respectively. 


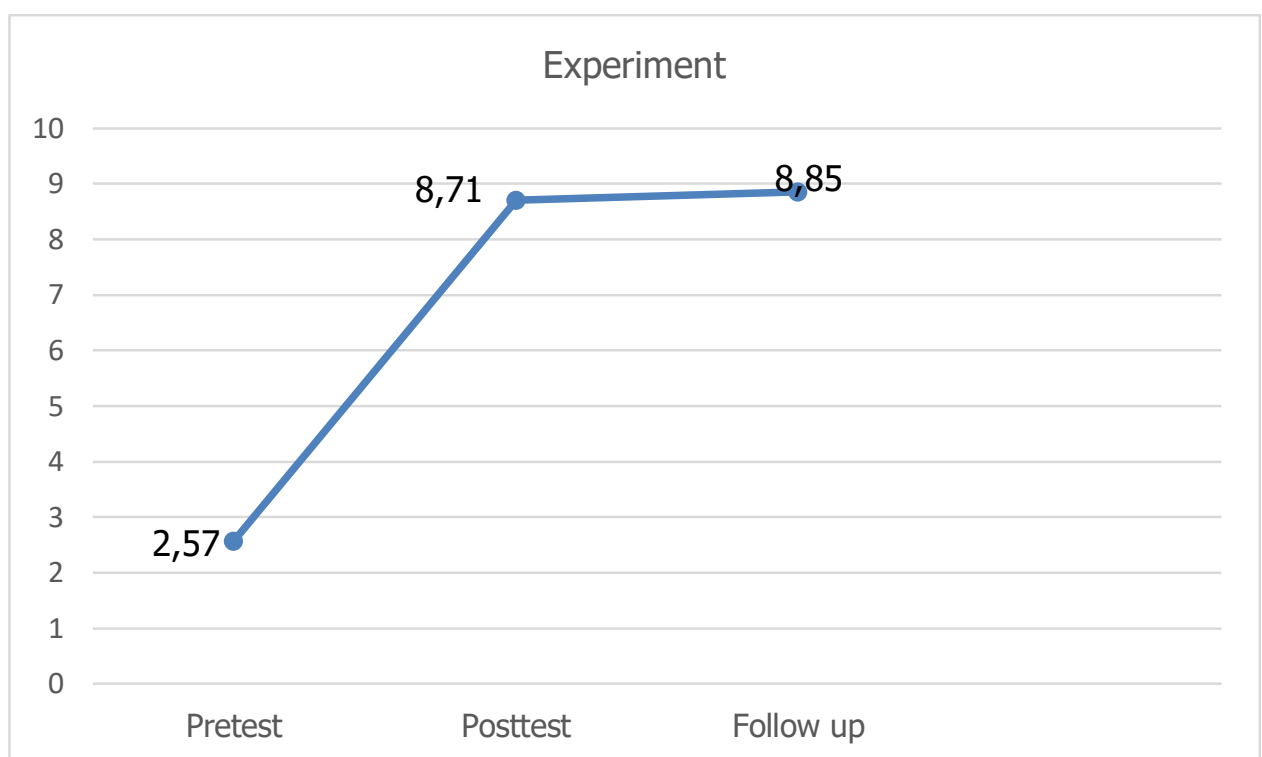

Figure 2. The mean scores for subjective well-being on the affective aspects

The results of subjective well-being data analysis performed through the Mann Whitney U Test on the cognitive aspects (life satisfaction) and affective aspects provided the evidence on the influences of gratitude training in improving subjective well-being of the adolescents in orphanages in each aspect (aspects of life satisfaction and affective aspects). These results are shown in Table 3.

Table 3

Subjective Well-being in the Experiment Group and Control Group Differences in Cognitive

\begin{tabular}{clll}
\hline Aspects & $\mathrm{Z}$ & $\mathrm{p}$ & Notes \\
\hline Cognitive (life satisfaction) & -2.989 & .003 & There are significant differences \\
Affective & -3.106 & .002 & There are significant differences \\
\hline
\end{tabular}

Furthermore, the results of subjective well-being data analysis on cognitive and affective aspects in the experiment group with the Wilcoxon test between pretest - posttest and between posttest - follow up showed that there was an increase between pretest and posttest, and also between posttest and follow up (Tables 4 and 5).

Table 4

The Subjective Well-being in the Experiment Group between Pretest-Posttest

\begin{tabular}{cccc}
\hline Aspects & $\mathrm{Z}$ & $\mathrm{P}$ & Notes \\
\hline Cognitive (life satisfaction) & -2.379 & .017 & There is a significant improvement \\
Affective & -2.366 & .018 & There is a significant improvement \\
\hline
\end{tabular}

Table 5

The Subjective Well-being in the Experiment Group between Posttest - Follow up

\begin{tabular}{cccc}
\hline Aspects & $\mathrm{Z}$ & $\mathrm{p}$ & Notes \\
\hline Cognitive (life satisfaction) & -.816 & .414 & There is no significant improvement \\
Affective & -.577 & .564 & There is no significant improvement \\
\hline
\end{tabular}




\section{Discussion}

The results show the influence of gratitude training in improving the subjective wellbeing on the cognitive aspects (life satisfaction) and affective aspects of the adolescents living in orphanages. This is indicated by an increase in the subjective well-being score after receiving the gratitude training. In addition, at the follow up stage, the subjective wellbeing of the adolescents was still in a relatively constant condition.

The sessions in the training were arranged systematically to guide the participants in practicing the identification for thoughts that support the emergence of gratitude for blessings, practicing compiling journals of gratitude, tracking down the source of their received blessings, realizing expressions of gratitude to the sources who gave the blessings. The session stages are intended to hone the participants' ability to think positively on their received blessings while living in the orphanage, and to bring out their subjective wellbeing - high life satisfaction - and developing positive affect. Adolescents who obtain life satisfaction are those who are able to think positively on their received blessings (Diener, 1994). Lynn \& Ellis (2010) contend that thoughts and feelings are interconnected, and they influence each other. The life satisfaction for God's blessings felt by adolescents living in orphanages can lead to positive emotional reactions. According to Diener, Suh, and Oishi (1997), a person who is satisfied with one's life and often feels positive emotions indicates that the person has a subjective well-being.

The outcome of the gratitude training is that cognitively the adolescents living in orphanages are able to realize that every event in their lives has a positive side that they must be grateful for. For example, the adolescents living in orphanages realize that being in an orphanage is a step towards achieving a better future. They are also able to think that the rules or activities in the orphanage have many benefits that make them interested in be involved in various daily activities. Adolescents can also have a positive view about their caregivers. They realize the advice and punishment given to the children who break the rules is a reasonable behavior and aims for the good of those children. Affectively, this training is also able to encourage the growth of positive emotions in the participants. After the treatment, adolescents accept the given punishment when they made a mistake, have the courage to tell the problems they experienced to their caregivers, and feel comfortable and happy to live in the orphanage even though they are far from their parents.

In general, all of the participants experienced subjective well-being improvements on the cognitive aspects (life satisfaction) and affective aspects between the pretest, posttest, and follow up-with varying degrees of improvement. The smallest increase in the subjective well-being score occurs in the participants who did not work on their homework on expressing their gratitude personally and optimally. These participants actually have already had an awareness of the goodness received from other people (caregivers), but their fear made them unable to communicate their feelings. Their fear of their caregivers is a manifestation of negative affect that can influence the cognitive (life satisfaction) aspects of subjective well-being on positive social relations. Soekamto (2012) contends that positive social relations can be realized if the social contact or communication to convey their intentions between individuals are made. Positive social relations will be realized if there is emotional intimacy - that makes a person be able to develop one's self-esteem and minimize psychological problems (Ariati, 2010). This is in line with Ryan \& Deci (2000) who state that psychological needs, i.e., close social relations with humans lead to a high subjective well-being. 
From the results of the interviews with the participants, it was revealed that the subjective well-being improvements in the cognitive aspects (life satisfaction) and affective aspects occurred in the participants who have had their optimism on their hopes or ideals after graduating from the orphanage. The results of the study of Lucas, Diener, \& Suh (1996) declare that there is a correlation between optimism and subjective well-being, i.e., the satisfaction in life, and also pleasant and unpleasant affection. Scheier \& Carver (1993) revealed that an always maintained optimism signifies a subjective well-being, since it has the hope to reach for a better future, and has a positive perception of the future and life. People who report that their lives are happier and more satisfied see their lives as more optimistic people. A person who is optimistic tends to feel that one's life is happier and more satisfied in looking at one's life, full of hope about one's future (Diener et al., 1999; Lounsbury et al., 2003).

The findings of this study confirm the statement of McCullough, Emmons, \& Tsang (2002) that grateful people often feel positive affects, including happiness, feeling life satisfaction, having a lot of expectations, and not easily feeling jealous, anxious, or depressed. According to McDonald \& Gorsuch (2004), being grateful is religious coping where a person uses one's beliefs to manage stress and life problems. McCullough, Kimeldorf, \& Cohen (2008) also stated that being grateful can bring pleasant emotions such as happiness, because gratitude will bring benefits to oneself and also to the hearts of others.

There are limitations in this study, including the need for stronger encouragement to the participants in the session of expressing personal gratitude, because it is hampered by them being embarrassed. This occurred to the participants of this study, in which from the 7 participants only 3 participants were able to express their personal gratitude. This shows that the instructor needs more effort to build the participants' awareness on the importance of the material, so the participants have the courage to express their feelings and have the willingness to write in their journal. The participants who showed a high increase were the participants who took part in the entire training series and they performed well on the given assignments.

\section{Conclusion}

The gratitude training is able to improve the subjective well-being of cognitive aspects (life satisfaction) and affective aspects that relatively settled on the adolescents living in orphanages. More optimal subjective well-being can be achieved by the adolescents who made full effort on their assignments, maintained the obtained activities during their training, were willing to initiate communication with their caregivers and were able to be optimistic about their future. From this research, the importance of building a grateful attitude for the received blessings in the participants' everyday life was revealed. Gratitude can be realized by positively making meaning of their lives' events in order to acquire life satisfaction both cognitively and affectively.

\section{References}

Aesiyah, S. (2013). Efektivitas pelatihan regulasi emosi untuk meningkatkan kebahagiaan remaja panti asuhan (The efectivity of emotiona regulation training to improve hapiness among teenagers living in orphages). Universitas Muhammadiyah Surakarta, Surakarta. 
Anggarani, F. K., Andayani, T. R., \& Karyanta, N. A. (2010). Pengaruh pelatihan syukur terhadap subjective well-being pada penduduk miskin di surakarta (The effect of gratitude training on subjective well-being among the poor in Surakarta city). Jurnal Ilmiah Psikologi Candrajiwa, 8(2), 44-59.

Ariati, J. (2010). Subjective well-being (kesejahteraan subjektif) dan kepuasan kerja pada staf pengajar (dosen) di lingkungan Fakultas Psikologi Universitas Diponegoro (Subjective well-being and work satisfaction among lecturers of Faculty of Psychology Universitas Diponegoro). Jurnal Psikologi Undip, 8(2), 117-123.

Clore, G. L., Ortony, A., \& Foss, M. A. (1987). The psychological foundations of the affective lexicon. Journal of Personality and Social Psychology, 53(4), 751-766.

Diener, E. (1994). Assessing subjective well being: progress and oportunities. Social Indicators Research, 31, 103-157.

Diener, E. (2000). Subjective well-being: The science of happiness and a proposal for a national index. American Psychologist, 55(1), 34-43.

Diener, E., \& Scollon, C. N. (2003). Subjective well-being is desirable, but not the summum bonum. Interdisciplinary Workshop on Well-Being, 1-20.

Diener, E., Suh, E., Lucas, R., \& Smith, H. (1999). Subjective well-being: Three decades of progress. Psychological Bulletin, 125(2), 276-302.

Diener, E., Suh, E., \& Oishi, S. (1997). Recent findings on subjective well being. Indian Journal of Clinical Psychology, 24(1), 276-302.

Emmons, R. A., \& McCullough, M. E. (2003). Counting blessings versus burdens: An experimental investigation of gratitude and subjective well being in daily life. Journal of Personality and Social Psychology, 84(2), 377-389.

Emmons, R. A., \& Shelton, C. M. (2002). Gratitude and the science of positive psychology. In C. R. Snyder \& S. J. Lopez (Eds.), Handbook of positive psychology (pp. 459-471). New York: Oxford University Press.

Etikan, I., Musa, S. A., \& Alkasim, R. S. (2016). Comparison of convenience sampling and purposive sampling. American Journal of Theoretical and Applied Statistics, 5(1), 1.

Gilek, M. (2010). The effect of a gratitude intervention on subjective well-being in a UK sample: the role of self-esteem. The University of Edinburgh.

Khairat, M., \& Adiyanti, M. (2015). Self-esteem dan Prestasi Akademik sebagai Prediktor Subjective Well-being Remaja Awal (Self-esteem and academic achievement as predictors of subjective well-being among early teens). Gadjah Mada Journal Of Psychology, 1(3), 180-191.

Kusumah, S. H. (2015). Efektivitas gratitude training terhadap peningkatan subjective well being pada buruh Sarung Alimin Majalaya (The efectivity of gratitude training to increase subjective well being among workers of Sarung Alimin Majalaya). Universitas Pendidikan Indonesia.

Latipun. (2002). Psikologi eksperimen (Experiment psychology). Malang: UMM Press.

Lounsbury, J. W., Loveland, J. M., Sundstrom, E. D., Gibson, L. W., Drost, A. W., \& Hamrick, F. L. (2003). An investigation of personality traits in relation to career satisfaction. Journal of Career Assessment, 11(3), 287-307.

Lucas, R. E., Diener, E., \& Suh, E. (1996). Discriminant validity of well being measures. Journal of Personality and Social Psychology, 71(3), 616-628.

Lynn, S. ., \& Ellis, A. (2010). Rational and irrational beliefs. New York: Oxford University Press.

McCullough, M. E., Emmons, R. A., \& Tsang, J. A. (2002). The grateful disposition: A conceptual and empirical topography. Journal of Personality and Social Psychology, 82(1), 112-127. 
Mccullough, M. E., Kimeldorf, M. B., \& Cohen, A. D. (2008). An adaptation for altruism? Current Directions in Psychological Science, 17(4), 281-285.

McDonald, A. W., \& Gorsuch, R. L. (2004). A multivariate theory of god concept, religious motivation, locus of control, coping and spiritual well being. Journal of Psychology and Theology, 32(4), 318-334.

Pavot, W., \& Diener, E. D. (2004). Well being in adulthood: Findings and implication. Ageing International, 29(2), 113-114.

Peterson, C., \& Seligman, M. E. P. (2004). Character strengths and virtues: A handbook and classification. New York: Oxford University Press.

Piko, B. ., \& Hamvai, C. (2010). Parent, school, and peer-related correlates of adolescents' life satisfaction. Children and Youth Service Review, 32(10), 1479-1482.

Ryan, R., \& Deci, E. (2000). Self-determination theory and the facilitation of intrinsic motivation, social development, and well-being. The American Psychologist, 55(1), $68-78$.

Sabiq, Z., \& Miftahuddin. (2017). Pengaruh optimisme, dukungan sosial, dan faktor demografis terhadap kesejahteraan subjektif pada perawat (The effect of optimism, social support and demographic factors on subjective well-being among nurses). JP3I, 6(2), 183-196.

Safitri, R. P. (2013). Terapi kebersyukuran berbasis kognitif perilaku untuk meningkatkan penerimaan diri pasien ginjal kronis yang menjalani hemodialisis (Cognitive based gratitude therapy to incrase self-acceptance among chronic kidney failure patients undergoing hemodialysis. Universitas Islam Indonesia, Yogyakarta.

Santoso, S. (2003). Mengatasi berbagai masalah statistik dengan SPSS versi 11,5 (Resolving statistic problems with SPSS version 11,5). Jakarta: Gramedia.

Scheier, M. F., \& Carver, C. S. (1993). On the power of positive thinking: Benefits of being optimistic. Current Directions in Psychological Science, 2(1), 26-30.

Sengendo, J., \& Nambi, J. (1997). The psychological effect of orphanhood: A study of orphans in rakai district. Health Transition Review: The Cultural, Social, and Behavioural Determinants of Health, 7, 105-124.

Soekamto. (2012). Sosiologi suatu pengantar (Introduction of sociology). Jakarta: Rajawali Press.

Watkins, P. (2003). Gratitude and happiness : Development of a measure of gratitude, and relationships with subjective well-being. Social Behavior and Personality, 31(5), 431-445.

Wood, A. M., Joseph, S., \& Maltby, J. (2009). Gratitude predicts psychological well-being above the Big Five facets. Journal Personality and Individual Differences, 46(4), 443-447.

Yuniana. (2013). Kesejahteraan subjektif pada yatim piatu (mustadh'afin) (Subjective well-being among orphan). Empathy Jurnal Fakultas Psikologi, 2(1), 1-11.

Zotova, O. Y., Tarasova, L. V., \& Syutkina, E. N. (2016). Features of subjective wellbeing characteristic of teenagers raised in two-parent families and orphanages. Procedia - Social and Behavioral Sciences, 233, 160-164. 